\title{
Fruits and vegetables consumption and the risk of histological subtypes of lung cancer in the European Prospective Investigation into Cancer and Nutrition (EPIC)
}

\author{
F. L. Büchner • H. B. Bueno-de-Mesquita • J. Linseisen - H. C. Boshuizen • L. A. L. M. Kiemeney $\cdot$ \\ M. M. Ros • K. Overvad • L. Hansen • A. Tjonneland • O. Raaschou-Nielsen • F. Clavel-Chapelon • \\ M.-C. Boutron-Ruault $\cdot$ M. Touillaud $\cdot$ R. Kaaks $\cdot$ S. Rohrmann $\cdot$ H. Boeing $\cdot$ U. Nöthlings $・$ \\ A. Trichopoulou $\cdot$ D. Zylis $\cdot$ V. Dilis $\cdot$ D. Palli $\cdot$ S. Sieri $\cdot$ P. Vineis $\cdot$ R. Tumino $\cdot$ S. Panico \\ P. H. M. Peeters • C. H. van Gils • E. Lund • I. T. Gram • T. Braaten • C. Martinez • \\ A. Agudo $\cdot$ L. Arriola $\cdot$ E. Ardanaz $\cdot$ C. Navarro $\cdot$ L. Rodríguez $\cdot$ J. Manjer $\cdot$ E. Wirfält $\cdot$ \\ G. Hallmans • T. Rasmuson • T. J. Key • A. W. Roddam • S. Bingham • K.-T. Khaw • \\ N. Slimani $\cdot$ P. Bofetta $\cdot$ G. Byrnes $\cdot$ T. Norat $\cdot$ D. Michaud $\cdot$ E. Riboli
}

Received: 7 May 2009/Accepted: 3 November 2009/Published online: 19 November 2009

(C) The Author(s) 2009. This article is published with open access at Springerlink.com

\begin{abstract}
Objective To examine the association between fruit and vegetable consumption and risk of different histological subtypes of lung cancer among participants of the European Prospective Investigation into Cancer and Nutrition study.
\end{abstract}

F. L. Büchner $(\square) \cdot$ H. B. Bueno-de-Mesquita

H. C. Boshuizen · M. M. Ros

National Institute of Public Health and the Environment (RIVM), P.O. Box 1, 3720 BA Bilthoven, The Netherlands e-mail: frederike.buchner@rivm.nl

F. L. Büchner · L. A. L. M. Kiemeney · M. M. Ros Department of Epidemiology, Biostatistics and HTA

Radboud University Nijmegen Medical Center, Nijmegen,

The Netherlands

J. Linseisen $\cdot$ R. Kaaks $\cdot$ S. Rohrmann

Division of Clinical Epidemiology, Deutsches

Krebsforschungszentrum, Heidelberg, Germany

\section{J. Linseisen}

Institute of Epidemiology, Helmholtz Zentrum München,

Neuherberg, Germany

\section{A. L. M. Kiemeney}

Department of Urology, Radboud University Nijmegen

Medical Centre, Nijmegen, The Netherlands

L. A. L. M. Kiemeney

Comprehensive Cancer Center East, Nijmegen, The Netherlands

\section{K. Overvad}

Department of Clinical Epidemiology, Aarhus University

Hospital, Aalbrog, Denmark
Methods Multivariable Cox proportional hazard models were used to analyze the data. A calibration study in a subsample was used to reduce dietary measurement errors. Results During a mean follow-up of 8.7 years, 1,830 incident cases of lung cancer (574 adenocarcinoma, 286 small cell, 137 large cell, 363 squamous cell, 470 other

L. Hansen · A. Tjonneland · O. Raaschou-Nielsen Institute of Cancer Epidemiology, Danish Cancer Society, Copenhagen, Denmark

F. Clavel-Chapelon · M.-C. Boutron-Ruault · M. Touillaud Inserm (Institut National de la Santé et de la Recherche Médicale), ERI 20/Université Paris-Sud, EA 4045, IFR 69/Institut Gustave-Roussy, Villejuif, France

H. Boeing · U. Nöthlings German Institute of Human Nutrition, Potsdam-Rehbücke, Germany

A. Trichopoulou · D. Zylis

Department of Hygiene and Epidemiology, University of Athens Medical School, Athens, Greece

A. Trichopoulou · V. Dilis

Hellenic Health Foundation, Athens, Greece

D. Palli

Molecular and Nutritional Epidemiology Unit, Cancer Research and Prevention Institute (ISPO), Florence, Italy

S. Sieri

Department of Epidemiology, National Cancer Institute,

Milan, Italy 
histologies) were identified. In line with our previous conclusions, we found that after calibration a $100 \mathrm{~g} / \mathrm{day}$ increase in fruit and vegetables consumption was associated with a reduced lung cancer risk (HR 0.94; 95\% CI 0.89-0.99). This was also seen among current smokers (HR 0.93 ; 95\% CI 0.90-0.97). Risks of squamous cell carcinomas in current smokers were reduced for an increase of $100 \mathrm{~g} /$ day of fruit and vegetables combined (HR $0.85 ; 95 \%$ CI 0.76-0.94), while no clear effects were seen for the other histological subtypes.

Conclusion We observed inverse associations between the consumption of vegetables and fruits and risk of lung cancer without a clear effect on specific histological subtypes of lung cancer. In current smokers, consumption of vegetables and fruits may reduce lung cancer risk, in particular the risk of squamous cell carcinomas.

Keywords Fruits - Vegetables - Lung neoplasms · Small cell lung carcinoma $\cdot$ Non-small-cell lung carcinoma $\cdot$ Adenocarcinoma $\cdot$ Large cell carcinoma

\section{Introduction}

Lung cancer is one of the most common cancers in men. Age-adjusted rates of lung cancer are decreasing among

P. Vineis · P. H. M. Peeters - T. Norat - D. Michaud · E. Riboli Department of Epidemiology and Public Health, Imperial College London, London, UK

P. Vineis

ISI Foundation, Torino, Italy

R. Tumino

Cancer Registry and Histopathology Unit, Department of

Oncology, "Civile M.P. Arezzo" Hospital, Ragusa, Italy

S. Panico

Department of Clinical and Experimental Medicine,

Federico II University, Medical School, Naples, Italy

P. H. M. Peeters - C. H. van Gils

Julius Center for Health Sciences and Primary Care,

University Medical Center Utrecht, Utrecht, The Netherlands

E. Lund · I. T. Gram · T. Braaten

Institute of Community Medicine, University of Tromso,

Tromso, Norway

C. Martinez

Andalusian School of Public Health, Granada, Spain

\section{A. Agudo}

Unit of Nutrition, Environment, and Cancer, Cancer

Epidemiology Research Program, Catalan Institute

of Oncology, Barcelona, Spain men in many high-income countries due to decreased smoking, but increasing in some low-income countries. In women, incidence rates are lower (globally, the age-standardized incidence rate is 12.1 per 100,000 women compared with 35.5 per 100,000 men), but rates among women continue to rise in many countries [1-3].

Lung cancer can be divided into four major histological subtypes: adenocarcinoma, small cell carcinoma, large cell carcinoma, and squamous cell carcinoma. Squamous cell carcinoma is the predominant histological type among men while in women adenocarcinoma is the most common subtype. The trends in subtypes of lung cancer incidence also vary by gender. In men, the incidence of squamous and small cell cancer is decreasing, while the incidence of adenocarcinoma is stable or slightly increasing in western countries. For women, the incidence of all histological subtypes is increasing, although most rapidly for adenocarcinoma [1].

The major risk factor for lung cancer is tobacco smoking $[1,4]$. Tobacco smoking is related to all histological subtypes of lung cancer, but the strength of the association differs with small cell carcinoma showing the strongest association followed by squamous cell carcinoma, while adenocarcinoma shows the weakest association with tobacco smoking [4]. Likewise, the effect of smoking cessation is the strongest for small cell carcinoma and the weakest for adenocarcinoma [5].

L. Arriola

Public Health Division of Gipuzkoa, Basque Government, CIBER en Epidemiología y Salud Pública (CIBERESP), San Sebastian, Spain

E. Ardanaz

Public Health Institute of Navarra, Pamplona, Spain

E. Ardanaz $\cdot$ C. Navarro

CIBER Epidemiología y Salud Pública (CIBERESP),

Pamplona, Spain

C. Navarro

Department of Epidemiology, Murcia Regional Health

Authority, Murcia, Spain

L. Rodríguez

Public Health and Participation Directorate, Health and Health

Care Services Council, Asturias, Spain

J. Manjer

Department of Surgery,

Malmö University Hospital, Malmö, Sweden

E. Wirfält

Nutrition Epidemiology, Department of Clinical Sciences

in Malmö, Lund University, Malmö, Sweden 
Vegetable and fruit consumption have also been hypothesized to influence lung cancer risk [6]. The 2007 WCRF/ AICR expert report, 'Food, Nutrition, Physical Activity, and the Prevention of Cancer: a Global Perspective', concludes that fruits probably protect against lung cancer and that there is only limited evidence suggesting that non-starchy vegetables, selenium, and foods containing it protect against lung cancer. The 2007 WCRF/AICR expert report does not mention differences in effect of fruit and vegetable consumption between the different histological subtypes of lung cancer [2]. There are indications that the association of vegetables and fruits may vary among the histological subtypes of lung cancer, but study results are inconsistent. A suggestion of a stronger inverse association for total fruits and vegetable consumption and total fruits in adenocarcinomas and squamous cell carcinomas compared to small cell carcinomas was shown in a pooled analysis of eight prospective studies [7].

The purpose of this article is to describe the associations between fruit and vegetable consumption and risks of the different histological subtypes of lung cancer among participants in the European Prospective Investigation into Cancer and nutrition (EPIC) study. The relation between total lung cancer incidence and fruit and vegetable consumption was previously investigated within EPIC by Miller et al. [6] and Linseisen et al. [8]. They both found a reduced risk for lung cancer with a high consumption of fruit $[6,8]$. Linseisen et al. [8], using a substantially larger number of cases than Miller et al. [6] (1,126 vs. 860 lung cancer cases), also found a reduced lung cancer risk with a high vegetable consumption in current smokers. With new follow-up data available, for the first time an adequate number of 1,830 lung cancer cases is available for the analyses of the association between fruit and vegetable consumption and risk of histological subtypes of lung cancer, overall and by smoking status.

\section{G. Hallmans}

Department of Public Health and Clinical Medicine,

Nutritional Research, University of Umeå, Umeå, Sweden

T. Rasmuson

Radiation sciences, Oncology, Umeå University,

Umeå, Sweden

\section{T. J. Key · A. W. Roddam}

Cancer Research UK Epidemiology Unit, University of Oxford, Oxford, UK

S. Bingham

MRC Dunn Human Nutrition Unit, Cambridge, UK

K.-T. Khaw

Department of Public Health and Primary Care, University of Cambridge School of Clinical Medicine, Cambridge, UK

N. Slimani $\cdot$ P. Bofetta $\cdot$ G. Byrnes

International Agency for Research on Cancer, Lyon, France

\section{Methods and materials}

\section{Study participants}

The European Prospective Investigation into Cancer and Nutrition (EPIC) is an ongoing multicenter cohort study designed to investigate the relations between diet, lifestyle and environmental factors, and the incidence of cancer. The total cohort consists of cohorts of men and women recruited in 23 centers in 10 European countries: Denmark, France, Germany, Greece, Italy, the Netherlands, Norway, Spain, Sweden, and the United Kingdom. The populations and methods have been described in full elsewhere [9]. In brief, the EPIC cohort consists of 521,468 subjects, mostly aged 25-70 years, recruited during the period 1991-2000 from the general population residing in a specific geographic area, a town or a province. Exceptions were the French cohort, which was based on members of the health insurance for state school employees, the Utrecht (the Netherlands) and the Florence (Italy) cohorts, which were both based on women attending breast cancer screening, components of the Italian and Spanish cohorts which included members of local blood donor organizations, and half of the Oxford (United Kingdom) cohort that was based on vegetarian and health-conscious volunteers. In France, Norway, Utrecht (the Netherlands), and Naples (Italy) only women were recruited. Eligible subjects were invited to participate in the study by mail or by personal contact. As a rule, those who participated signed an informed consent form, and diet and lifestyle questionnaires were mailed to them, except in all Spanish centers, Greece, and Ragusa (Italy), where interviewer-administered questionnaires were used. In most countries, study subjects were invited to visit a center for blood collection and anthropometric measurements and to deliver the completed diet and lifestyle questionnaires [9].

\section{Diet and lifestyle questionnaires}

At baseline, usual diet before enrollment was measured by country-specific validated questionnaires designed to capture local dietary habits. Although the design of the questionnaires was based on the same general format, there were differences between the questionnaires used in several countries. Extensive self-administered quantitative dietary questionnaires were used in northern Italy, the Netherlands, Germany, and Greece. In France, Spain, and Ragusa (Italy), questionnaires similar to the dietary questionnaires, but structured by meals, were used. To increase the compliance, the centers in Spain and Ragusa performed a face-to-face dietary interview using a computerized dietary program. Semi-quantitative food frequency questionnaires with the same standard portion assigned to all 
participants were used in Denmark, Norway, Naples (Italy), and Umeå (Sweden). In Malmö (Sweden), a nonquantitative food frequency questionnaire was combined with a 14-day record on hot meals, and in the United Kingdom a semi-quantitative food frequency questionnaire and a 7-day record were used [9].

The food groups analyzed were vegetables and fresh fruits (excluding olives, nuts, seeds, and fruit juices). Analyses were also carried out for subgroups of vegetables (leafy vegetables, fruiting vegetables, cabbages, root vegetables, mushrooms, and garlic and onions) and subgroups of fresh fruits (hard fruit (including apples and pears), stone fruit (including cherry, mirabelle, plum, apricot, peach, and nectarine), berries, grapes, and citrus fruit (excluding and including citrus juices)). Additionally, legumes (including grain and pod vegetables) are analyzed as a separate group. Details of food items included in the selected vegetables and fruits subgroups used in the analysis have been reported in full by Agudo et al. [10].

Lifestyle questionnaires included questions on education, occupation, medical history, lifetime history of consumption of tobacco, alcoholic beverages, and physical activity [9].

\section{Endpoints}

Follow-up was based on population-based cancer registries in seven of the participating countries: Denmark, Italy, Netherlands, Spain, Sweden, United Kingdom, and Norway. In France, Germany, and Greece, a combination of methods was used, including health insurance records, cancer and pathology hospital registries, and active followup. Mortality data were also collected from registries at the regional or national level [9]. Censoring dates for complete follow-up were as follows: December 2002 (Granada); December 2003 (Florence, Varese, Naples, Murcia, Bilthoven and Denmark); December 2004 (Ragusa, Turin, Asturias, Navarra, United Kingdom, Utrecht, Malmo and Norway); June 2005 (France); December 2005 (San Sebastian and Umea). For Germany and Greece, the end of follow-up was considered to be the last known contact, the date of diagnosis or the date of death, whichever came first.

Cancer of the lung was defined as code C 34 of the 10th revision of the International Statistical Classification of Diseases, Injuries, and Causes of Death (ICD). According to the morphology codes of the WHO International Histological Classification of Tumors, histological types were classified into four major histological types: squamous cell carcinoma $(8052,8070-8073,8075$, and 8123), small cell carcinoma (8041-8045 and 8246), large cell carcinoma $(8012,8020-8021$, and 8082), and adenocarcinoma $(8140,8143,8200,8211,8230,8250$ $8251,8260,8300,8310,8480-8481,8490$, and 8550).
Other histological types (8010-8011, 8022, 8030-8032, $8046,8240,8243,8430,8560,8710,8720,8800-8801$, 9120, 9133, 9590, 9591, 9671, and 9699) and unclassified histological types of carcinomas (8000-8001 and missing histological data) were placed into a miscellaneous category. Only first incident lung cancer cases were taken into account.

\section{Statistical methods}

Cox proportional hazards regression was used to analyze the association between fruit and vegetable consumption and risk of different histological subtypes of lung cancer. Age was used as the primary time variable in the models with entry time defined as age at recruitment and exit time as age at diagnosis, age at death, or age at end of follow-up, whichever came first. All analyses were stratified by age at recruitment (in 1-year categories) to control for length of follow-up, and by gender and center to control for country effects such as follow-up procedures, and questionnaire design. The proportional hazard assumption, that was tested by introducing an interaction term between time and the exposure variable, was met. Cases diagnosed after censoring date were considered as non-cases. When analyzing the different histological subgroups of lung cancers, the histological subtypes not of interest were censored at time of diagnosis.

Consumption of vegetables and fruits and of vegetable and fruit subgroups was divided into EPIC-wide quintiles, using the lowest quintile as reference category. The consumption of vegetables and fruits was also analyzed continuously (per $100 \mathrm{~g} /$ day increase). Subgroups of vegetables and fruit were analyzed per $25 \mathrm{~g} /$ day increase. Analyses were also performed separately by smoking status and by gender. Interaction (on the multiplicative scale) was tested using the interaction term of fruit and/or vegetable consumption (in quintiles) with gender and smoking status.

We controlled, in the overall model, for smoking status (current, former, never), duration of smoking (continues in years; former and current smokers), lifetime intensity of smoking (continues in cigarettes/day; former and current smokers), the number of cigarettes smoked at baseline (continues in cigarettes/day; current smokers), and time since quitting (continues in years; former smokers). Additionally, we included the number of cigarettes at baseline squared and two interaction terms, one for the duration of smoking and the number of cigarettes at baseline and one for the duration of smoking and age at start of smoking. Individuals with unknown smoking status $(n=7164$; $1.5 \%)$ were excluded from the Cox regression analyses. Indicator variables were used for missing values related to the intensity (20\% missing values), duration (5\% missing values), and age at start of smoking ( $3 \%$ missing values). 
All models additionally included height (continues in $\mathrm{cm}$ ), weight (continues in $\mathrm{kg}$ ), energy intake from fat and nonfat sources (continues in $\mathrm{kcal} / \mathrm{day}$ ), alcohol consumption (continues in g/day), physical activity (inactive, moderately inactive, moderately active, active, missing), and highest educational level (none, primary school, technical/professional school, secondary school, university). Within the analyses of fruits, we also adjusted for the intake of vegetables and vice versa (continues in grams/day). When analyzing subgroups of vegetables and fruits, also other vegetables and fruits consumption were controlled for. All covariates were included as separate variables on a continuous scale except when stated differently.

We derived probability values for a linear trend across quintiles from regression models using the median consumption within the quintiles as a continuous variable, hereby taking the unequal distances of the quintiles into account [11].

To evaluate whether preclinical disease may have influenced results, additional analyses were conducted after exclusion of cases that were diagnosed within 2 years after recruitment. To separate early from late effects in the natural course, we conducted analyses stratified by median follow-up.

\section{Calibration}

To reduce systematic over- and underestimation of dietary intakes across participating centers and to reduce measurement bias in hazard ratios $[12,13]$, a calibration method was additionally applied as described in detail by Ferrari et al. 2008 [13]. In brief, 24-h recall data were collected from an $8 \%$ sample of the cohort. The $24-\mathrm{h}$ recall values were regressed on the dietary questionnaire values for the main food groups and the subgroups in a linear calibration model [13]. Zero consumption values in the main dietary questionnaires were included in the regression calibration models. Data were weighted by day of the week and season of the year on which the 24 -h recall data were collected. Country and sex-specific calibration models were used to obtain individual calibrated values of dietary exposure for all participants. Cox regression models were then applied using the calibrated values for each individual on a continuous scale. The standard error of the deattenuated coefficient was calculated with bootstrap sampling ( $n=20$ repetitions) in the calibration and disease models consecutively [13].

All analyses were performed using SAS version 9.1 (SAS Institute Inc. Cary, NC).

\section{Results}

For the analyses, we excluded participants with a history of cancer at baseline ( $n=23,633)$, participants with incomplete follow-up information ( $n=3,446$ ), or participants with a ratio of energy intake versus energy expenditure in the top and bottom $1 \%$ ( $n=15,834)$. After these exclusions, there were no individuals with missing dietary data. A total of 478,535 participants were left for analyses.

After a mean follow-up of 8.7 years, 1,830 participants were newly diagnosed with a first incident lung cancer, i.e., 574 were classified as adenocarcinomas, 286 as small cell carcinomas, 137 as large cell carcinomas, and 363 as squamous cell carcinomas; 256 cases had other specified histologies and the histology was not specified for 214 participants. Eighty percent of the tumors were microscopically confirmed of which $82 \%$ histologically confirmed (65\% of the total number of cases).

Table 1 shows the frequency of lung cancers included in the analysis by country and gender. Adenocarcinomas were more common in women $(41 \%)$ than in men $(28 \%)$, while squamous cell carcinomas were more common among men (27\%) than among women (14\%). Overall, $89 \%$ of the lung cancer cases were ever smokers; $98 \%$ of the small cell carcinomas were ever smokers versus $87 \%$ of the adenocarcinoma cases.

Selected characteristics across quintiles of total vegetables and total fruits intake are shown in Table 2. With increasing consumption of vegetables and of fruits, the percentage of women increases. A higher consumption of vegetables and fruits was related to a higher intake of energy but a lower consumption of red and processed meat. Those reporting higher consumption of vegetables and of fruits were more likely to be never smokers and to be physically active.

\section{Fruits and vegetables combined}

Increasing fruit and vegetable consumption by $100 \mathrm{~g} /$ day was associated with a borderline statistically significant hazard ratio (HR) for lung cancer of 0.98 with a $95 \%$ confidence interval (95\% CI) of 0.96-1.00. After calibration, a $100 \mathrm{~g} /$ day increase in fruit and vegetables consumption was associated with a $6 \%$ reduction in lung cancer risk. None of the (un)calibrated risk estimates for the histological subtypes of cancer was statistically significant (Table 4). There was no heterogeneity by country ( $p$ for interaction with country was 0.94).

Among current smokers, a statistically significant inverse association was observed between consumption of fruit and vegetables and lung cancer risk that remained statistically significant after calibration (HR 0.93; 95\% CI 0.90-0.97). After calibration, a $100 \mathrm{~g} /$ day increase in consumption of fruit and vegetables in current smokers was associated with a $15 \%$ reduction in risk of squamous cell carcinoma, while no effects were seen for the other histological subtypes of lung cancer (Table 4). 
Table 1 Incidence of lung cancer within the EPIC cohort, 1993-1998

\begin{tabular}{|c|c|c|c|c|c|c|c|c|c|}
\hline \multirow[t]{2}{*}{ Country } & \multirow{2}{*}{$\begin{array}{l}\text { Person } \\
\text { years }\end{array}$} & \multirow{2}{*}{$\begin{array}{l}\text { First } \\
\text { incident } \\
\text { lung cancer }\end{array}$} & \multirow{2}{*}{$\begin{array}{l}\text { Incidence } \\
\text { rate per } 100,000 \\
\text { person years }^{\mathrm{a}}\end{array}$} & \multicolumn{6}{|c|}{ Histology of the tumor $n(\%)$} \\
\hline & & & & Adenocarcinoma & $\begin{array}{l}\text { Small } \\
\text { cell } \\
\text { carcinoma }\end{array}$ & $\begin{array}{l}\text { Squamous } \\
\text { cell } \\
\text { carcinoma }\end{array}$ & $\begin{array}{l}\text { Large } \\
\text { cell } \\
\text { carcinoma }\end{array}$ & $\begin{array}{l}\text { Other } \\
\text { histologies }\end{array}$ & $\begin{array}{l}\text { Not } \\
\text { specified }\end{array}$ \\
\hline \multicolumn{10}{|l|}{ Women } \\
\hline France & $7,41,203$ & 129 & 18.4 & 4 & 0 & 0 & 0 & 1 & 124 \\
\hline Italy & $2,57,356$ & 60 & 29.2 & 29 & 7 & 9 & 0 & 9 & 6 \\
\hline Spain & $2,41,319$ & 23 & 10.3 & 12 & 0 & 1 & 8 & 2 & 0 \\
\hline Greece & $1,08,501$ & 11 & 2.1 & 4 & 1 & 0 & 1 & 2 & 3 \\
\hline United Kingdom & $4,41,686$ & 100 & 29.4 & 38 & 11 & 15 & 2 & 26 & 8 \\
\hline The Netherlands ${ }^{\mathrm{b}}$ & $2,28,924$ & 99 & 45.0 & 41 & 16 & 16 & 16 & 9 & 1 \\
\hline Germany & $2,27,267$ & 41 & 24.9 & 18 & 7 & 3 & 2 & 10 & 1 \\
\hline Sweden & $2,71,071$ & 116 & 45.2 & 47 & 19 & 21 & 23 & 5 & 1 \\
\hline Denmark & $2,16,031$ & 219 & 91.1 & 85 & 47 & 30 & 11 & 41 & 5 \\
\hline Norway & $2,10,300$ & 68 & 46.0 & 29 & 15 & 7 & 0 & 15 & 2 \\
\hline Total & $2,943,660$ & 866 & 42.7 & $307(41 \%)^{\mathrm{c}}$ & $123(17 \%)^{\mathrm{c}}$ & $102(14 \%)^{\mathrm{c}}$ & $63(9 \%)^{\mathrm{c}}$ & $120(16 \%)^{\mathrm{c}}$ & $151(4 \%)^{\mathrm{c}}$ \\
\hline \multicolumn{10}{|l|}{ Men } \\
\hline \multicolumn{10}{|l|}{ France $^{\mathrm{d}}$} \\
\hline Italy & $1,18,770$ & 77 & 97.0 & 27 & 11 & 17 & 4 & 11 & 7 \\
\hline Spain & $1,53,853$ & 109 & 86.2 & 29 & 18 & 30 & 16 & 9 & 7 \\
\hline Greece & 73,446 & 79 & 107.2 & 18 & 11 & 15 & 1 & 12 & 22 \\
\hline United Kingdom & $1,90,483$ & 132 & 50.3 & 18 & 15 & 56 & 3 & 36 & 4 \\
\hline The Netherlands ${ }^{\mathrm{b}}$ & 81,362 & 38 & 141.6 & 14 & 7 & 11 & 5 & 1 & 0 \\
\hline Germany & $1,74,196$ & 145 & 105.4 & 42 & 39 & 28 & 5 & 20 & 11 \\
\hline Sweden & $2,29,535$ & 139 & 62.6 & 46 & 25 & 32 & 31 & 3 & 2 \\
\hline Denmark & $1,95,820$ & 245 & 116.7 & 73 & 37 & 72 & 9 & 44 & 10 \\
\hline \multicolumn{10}{|l|}{ Norway $^{\mathrm{d}}$} \\
\hline Total & $12,17,466$ & 964 & 76.7 & $267(28 \%)$ & $163(17 \%)$ & $261(27 \%)$ & $74(8 \%)$ & $136(14 \%)$ & $63(7 \%)$ \\
\hline
\end{tabular}

${ }^{a}$ For each country (5-year) age-standardized (European standard population) incidence rates were computed for the common age band of $50-69$ years of age

${ }^{\mathrm{b}}$ One of the two Dutch EPIC centers (Utrecht) consists of women only

${ }^{c}$ Percentages based on data without France because of the large number of non specified tumors

d The France and Norwegian cohorts consist of women only

Fruits

In the categorical analyses, consumption of fruits was statistically significantly inversely associated with lung cancer risk (Table 3). Compared to the lowest quintile, the HR and 95\% CI for those in the highest quintile of consumption was $0.80(0.66-0.96)$ with a statistically significant test for trend ( $p$-value 0.01). Suggestions of non-significant lower risks with increasing consumption of fruits were found for small cell, squamous cell, and adenocarcinomas.

For current smokers, results for fruits were consistent with those of the full cohort ( $p$ for trend 0.04), with strongest inverse association found for squamous cell carcinoma (HR 0.61; 95\% CI 0.34-1.10 comparing highest quintile with the lowest; $p$-trend $=0.07$ ). The test for interaction with smoking was borderline significant $(p=0.09)$. No clear associations in former and never smokers were seen, not overall nor for any of the subtypes of lung cancer for which adequate numbers were available. Stratification by gender showed somewhat stronger associations among women and a significant decreasing risk trend for small cell carcinoma ( $p$ for interaction with gender was 0.50).

Increasing fruit consumption with $100 \mathrm{~g} /$ day was associated with a small borderline statistically significant lower risk of lung cancer which was more pronounced for squamous cell carcinoma (Table 4). The calibrated risk estimates were somewhat stronger but not statistically significant. Because linear analyses are more sensitive to outliers, we performed a sensitivity analysis for total fruits in the full cohort by substituting values higher than $600 \mathrm{~g} /$ day with the value of $600 \mathrm{~g} /$ day $(95$ percentile of total fruit 
Table 2 Baseline characteristics by quintiles of observed intake of total vegetables and of total fruits in mean (SD)

\begin{tabular}{|c|c|c|c|c|c|c|}
\hline & \multirow[t]{2}{*}{ Full cohort } & \multicolumn{5}{|c|}{ Total vegetable and fruit consumption ${ }^{\mathrm{a}}$} \\
\hline & & 1 & 2 & 3 & 4 & 5 \\
\hline Cut-off values quintiles (g/day) ${ }^{\mathrm{b}}$ & - & $\leq 221$ & $222-330$ & $331-453$ & $454-635$ & $\geq 636$ \\
\hline \multicolumn{7}{|l|}{ General characteristics } \\
\hline $\operatorname{Men}(\%)$ & 30 & 44 & 32 & 26 & 22 & 26 \\
\hline Age at recruitment (year) & $51(9.9)$ & $50(9.7)$ & $51(9.8)$ & $51(9.8)$ & $52(9.8)$ & $52(10.4)$ \\
\hline BMI $\left(\mathrm{kg} / \mathrm{m}^{2}\right)$ & $25.4(4.3)$ & $25.4(4.1)$ & $25.3(4.1)$ & $25.1(4.1)$ & $25.2(4.3)$ & $26.0(4.6)$ \\
\hline Height $(\mathrm{cm})$ & $166.0(8.9)$ & $169.0(9.1)$ & $167.2(8.9)$ & $165.8(8.7)$ & $164.4(8.4)$ & $163.5(8.4)$ \\
\hline Weight (kg) & $70.2(13.7)$ & $72.8(14.1)$ & $70.9(13.7)$ & $69.3(13.3)$ & $68.3(13.1)$ & $69.7(13.5)$ \\
\hline Physically active $(\%)^{\mathrm{c}}$ & 41.0 & 45.7 & 46.3 & 46.1 & 46.4 & 52.6 \\
\hline \multicolumn{7}{|l|}{ Diet } \\
\hline Energy (kcal/day) & $2,084.6(622.0)$ & $1,909.3(609.2)$ & $2,006.7(596.3)$ & $2,068.8(590.5)$ & $2,142.6(602.5)$ & $2,295.4(641.1)$ \\
\hline Energy from fat sources (kcal/day) & $749.0(275.1)$ & $694.7(264.3)$ & $716.7(258.0)$ & $729.3(255.0)$ & $754.4(260.4)$ & $849.8(307.5)$ \\
\hline $\begin{array}{l}\text { Energy from non-fat sources } \\
\text { (kcal/day) }\end{array}$ & $1,335.6(407.0)$ & $1,214.6(395.1)$ & $1,290.0(383.5)$ & $1,339.5(383.1)$ & $1,388.2(398.2)$ & $1,445.5(433.7)$ \\
\hline Calibrated fruit consumption (g/day) & $208.9(108.5)$ & $112.8(47.4)$ & $159.9(56.9)$ & $202.1(66.4)$ & $246.7(77.3)$ & $323.2(129.6)$ \\
\hline $\begin{array}{l}\text { Calibrated vegetable consumption } \\
\text { (g/day) }\end{array}$ & $171.2(54.3)$ & $124.2(29.0)$ & $146.6(31.9)$ & $165.4(36.8)$ & 189.4 (41.9) & $230.3(55.7)$ \\
\hline Alcohol non-consumers (\%) & 7.3 & 7.1 & 7.1 & 6.9 & 7.8 & 8.3 \\
\hline Alcohol consumption (g/day) ${ }^{\mathrm{d}}$ & 6.6 & 7.1 & 7.1 & 6.9 & 6.5 & 5.3 \\
\hline Red and processed meat (g/day) & $76.8(51.7)$ & $85.2(52.7)$ & $82.4(52.1)$ & $77.2(51.3)$ & $72.3(50.2)$ & $66.9(50.0)$ \\
\hline \multicolumn{7}{|l|}{ Smoking status } \\
\hline Never smokers $(\%)$ & 49 & 38 & 45 & 51 & 55 & 57 \\
\hline Former smokers $(\%)$ & 27 & 26 & 28 & 28 & 26 & 24 \\
\hline Lifetime number of cigarettes (cig/day) & $13.1(9.3)$ & $13.4(9.3)$ & $12.3(8.6)$ & $12.2(8.4)$ & $12.6(8.7)$ & $15.1(10.8)$ \\
\hline Smoke duration (years) & $18.4(11.1)$ & $18.5(11.2)$ & $18.2(11.1)$ & $18.1(11.0)$ & $18.0(10.9)$ & $18.7(11.1)$ \\
\hline Age at start of smoking (years) & $18.9(5.1)$ & $18.1(5.6)$ & $18.2(5.8)$ & $18.2(6.3)$ & $18.1(6.6)$ & $18.2(6.8)$ \\
\hline Time since quitting smoking (years) & $15.2(10.3)$ & $14.6(10.1)$ & $15.3(10.2)$ & $15.5(10.3)$ & $15.6(10.3)$ & $14.7(10.2)$ \\
\hline Current smokers (\%) & 22 & 34 & 25 & 20 & 17 & 17 \\
\hline Lifetime number of cigarettes (cig/day) & $13.5(7.5)$ & $14.4(7.3)$ & $13.0(6.9)$ & $12.4(6.9)$ & $12.4(7.3)$ & $14.4(8.9)$ \\
\hline Smoke duration (years) & $30.1(10.1)$ & $31.2(9.8)$ & $30.8(10.0)$ & $30.3(10.1)$ & $29.4(10.1)$ & $27.5(10.7)$ \\
\hline Age at start of smoking (years) & $19.6(6.3)$ & $18.4(5.9)$ & $19.1(6.6)$ & $19.4(7.1)$ & $19.7(7.4)$ & $20.3(7.7)$ \\
\hline Unknown $(\%)$ & 2 & 1 & 1 & 1 & 2 & 2 \\
\hline \multicolumn{7}{|l|}{ Education level (\%) } \\
\hline None & 4 & 2 & 2 & 3 & 5 & 9 \\
\hline Primary school & 24 & 29 & 24 & 21 & 20 & 24 \\
\hline Technical/professional school & 23 & 30 & 28 & 23 & 19 & 14 \\
\hline Secondary school & 23 & 18 & 21 & 25 & 27 & 26 \\
\hline University degree & 24 & 20 & 24 & 26 & 26 & 24 \\
\hline Not specified & 2 & 1 & 2 & 2 & 3 & 3 \\
\hline
\end{tabular}

${ }^{\mathrm{a}}$ Excluding juices, nuts, seeds, and olives

b Calibrated interquintile range 258.2-486.1 g/day

${ }^{c}$ Physically active as defined by the Combined Total Physical Activity Index that categorizes the population into two activity levels based on a cross-tabulation of occupational activity by household and recreational activity

${ }^{d}$ Median consumption of alcohol excluding non-consumers

consumption). We found a slightly stronger uncalibrated hazard ratio of 0.96 with $95 \%$ CI of $0.92-1.00$ $(p$-value $=0.03)$. After calibration, higher consumption of fruits was statistically significantly inversely associated with the risk of squamous cell carcinomas in current smokers (Table 4). 
Table 3 Fully adjusted hazard ratios for different histological subtypes of lung cancer by quintiles (cut point of the quintiles are (g/day): $\leq 90$; 91-155; 156-238; 239-356; $\geq 357$ ) of observed fruit consumption for the full cohort, by smoke status and by gender

\begin{tabular}{|c|c|c|c|c|c|}
\hline $\begin{array}{l}\text { Fruit consumption } \\
\text { (gram per day) }\end{array}$ & Lung cancer & Adenocarcinoma & $\begin{array}{l}\text { Small cell } \\
\text { carcinoma }\end{array}$ & $\begin{array}{l}\text { Large cell } \\
\text { carcinoma }\end{array}$ & $\begin{array}{l}\text { Squamous cell } \\
\text { carcinoma }\end{array}$ \\
\hline Full cohort $(478,535)$ & 1,830 & 574 & 286 & 137 & 363 \\
\hline Q1 & 1.00 & 1.00 & 1.00 & 1.00 & 1.00 \\
\hline Q2 & $0.97(0.85-1.11)$ & $1.12(0.89-1.41)$ & $1.04(0.76-1.42)$ & $1.00(0.61-1.63)$ & $1.00(0.75-1.32)$ \\
\hline Q3 & $0.82(0.71-0.96)$ & $0.89(0.68-1.17)$ & $0.74(0.50-1.10)$ & $0.74(0.41-1.34)$ & $0.76(0.54-1.07)$ \\
\hline Q4 & $0.88(0.74-1.03)$ & $0.91(0.67-1.22)$ & $0.85(0.55-1.32)$ & $1.70(1.00-2.88)$ & $0.82(0.56-1.20)$ \\
\hline Q5 & $0.80(0.66-0.96)$ & $0.85(0.60-1.19)$ & $0.77(0.46-1.27)$ & $1.07(0.54-2.14)$ & $0.77(0.50-1.19)$ \\
\hline$p$ for trend & 0.01 & 0.20 & 0.21 & 0.39 & 0.16 \\
\hline Current smokers $(107,415)$ & 1,167 & 336 & 235 & 102 & 249 \\
\hline Q1 & 1.00 & 1.00 & 1.00 & 1.00 & 1.00 \\
\hline Q2 & $0.96(0.82-1.13)$ & $0.94(0.70-1.26)$ & $1.16(0.82-1.62)$ & $1.06(0.61-1.83)$ & $0.99(0.71-1.38)$ \\
\hline Q3 & $0.74(0.61-0.90)$ & $0.84(0.59-1.20)$ & $0.70(0.45-1.10)$ & $0.72(0.36-1.44)$ & $0.67(0.43-1.04)$ \\
\hline Q4 & $0.89(0.72-1.10)$ & $0.82(0.55-1.23)$ & $0.88(0.53-1.44)$ & $1.88(1.03-3.45)$ & $0.82(0.51-1.32)$ \\
\hline Q5 & $0.79(0.62-1.02)$ & $0.86(0.54-1.36)$ & $0.85(0.48-1.51)$ & $0.90(0.38-2.16)$ & $0.61(0.34-1.10)$ \\
\hline$p$ for trend & 0.04 & 0.39 & 0.37 & 0.59 & 0.07 \\
\hline Former smokers $(127,530)$ & 467 & 161 & $45^{\mathrm{a}}$ & $25^{\mathrm{a}}$ & 104 \\
\hline Q1 & 1.00 & 1.00 & & & 1.00 \\
\hline Q2 & $0.99(0.75-1.31)$ & $1.71(1.05-2.76)$ & & & $1.09(0.60-1.95)$ \\
\hline Q3 & $0.92(0.68-1.23)$ & $1.00(0.58-1.74)$ & & & $1.17(0.64-2.15)$ \\
\hline Q4 & $0.77(0.55-1.08)$ & $0.93(0.51-1.69)$ & & & $0.85(0.41-1.76)$ \\
\hline Q5 & $0.84(0.59-1.21)$ & $1.09(0.57-2.09)$ & & & $1.13(0.55-2.34)$ \\
\hline$p$ for trend & 0.24 & 0.53 & & & 0.90 \\
\hline Never smokers $(236,426)$ & 187 & 76 & $2^{\mathrm{a}}$ & $10^{\mathrm{a}}$ & $9^{\mathrm{a}}$ \\
\hline Q1 & 1.00 & 1.00 & & & \\
\hline Q2 & $1.18(0.67-2.09)$ & $1.36(0.58-3.22)$ & & & \\
\hline Q3 & $1.24(0.71-2.15)$ & $1.41(0.59-3.34)$ & & & \\
\hline Q4 & $1.46(0.84-2.53)$ & $1.64(0.68-3.94)$ & & & \\
\hline Q5 & $0.94(0.50-1.77)$ & $0.80(0.28-2.31)$ & & & \\
\hline$p$ for trend & 0.63 & 0.48 & & & \\
\hline Women $(335,886)$ & 866 & 307 & 123 & 63 & 102 \\
\hline Q1 & 1.00 & 1.00 & 1.00 & 1.00 & 1.00 \\
\hline Q2 & $0.91(0.75-1.11)$ & $1.01(0.73-1.39)$ & $1.04(0.66-1.64)$ & $0.57(0.26-1.29)$ & $0.95(0.55-1.63)$ \\
\hline Q3 & $0.77(0.62-0.96)$ & $0.92(0.65-1.32)$ & $0.47(0.25-0.88)$ & $0.86(0.39-1.93)$ & $0.66(0.34-1.28)$ \\
\hline Q4 & $0.84(0.67-1.06)$ & $0.82(0.55-1.22)$ & $0.61(0.32-1.15)$ & $1.40(0.66-2.98)$ & $1.07(0.57-2.00)$ \\
\hline Q5 & $0.77(0.59-1.00)$ & $0.80(0.51-1.27)$ & $0.54(0.25-1.19)$ & $0.86(0.31-2.37)$ & $0.76(0.33-1.76)$ \\
\hline$p$ for trend & 0.06 & 0.23 & 0.04 & 0.61 & 0.67 \\
\hline Men $(142,649)$ & 964 & 267 & 163 & 74 & 261 \\
\hline Q1 & 1.00 & 1.00 & 1.00 & 1.00 & 1.00 \\
\hline Q2 & $1.03(0.86-1.23)$ & $1.25(0.90-1.74)$ & $0.99(0.64-1.53)$ & $1.40(0.76-2.60)$ & $1.02(0.73-1.42)$ \\
\hline Q3 & $0.88(0.71-1.08)$ & $0.85(0.56-1.29)$ & $1.06(0.65-1.75)$ & $0.54(0.21-1.36)$ & $0.82(0.55-1.22)$ \\
\hline Q4 & $0.92(0.72-1.17)$ & $1.06(0.68-1.66)$ & $1.16(0.65-2.09)$ & $1.81(0.85-3.84)$ & $0.71(0.43-1.15)$ \\
\hline Q5 & $0.82(0.63-1.08)$ & $0.93(0.56-1.56)$ & $1.04(0.53-2.03)$ & $1.12(0.43-2.93)$ & $0.77(0.46-1.30)$ \\
\hline$p$ for trend & 0.12 & 0.63 & 0.82 & 0.67 & 0.20 \\
\hline
\end{tabular}

Cox regression model adjusted for vegetable consumption, smoking status, duration of smoking, lifetime and baseline intensity of smoking, time since quitting, energy intake, weight, height, alcohol consumption, physical activity, and school level

${ }^{\text {a }}$ Too few cases to get reliable results 
Table 4 Fully adjusted hazard ratios for different histological subtypes of lung cancer by increasing observed and calibrated total fruit and vegetable consumption (per $100 \mathrm{~g} /$ day) for the full cohort, by smoke status and by gender

\begin{tabular}{|c|c|c|c|c|c|}
\hline & Lung cancer & Adenocarcinoma & Small cell carcinoma & $\begin{array}{l}\text { Large cell } \\
\text { carcinoma }\end{array}$ & $\begin{array}{l}\text { Squamous cell } \\
\text { carcinoma }\end{array}$ \\
\hline Full cohort $(478,535)$ & 1,830 & 574 & 286 & 137 & 363 \\
\hline Fruit and vegetables & $0.98(0.96-1.00)$ & $0.97(0.93-1.02)$ & $0.97(0.91-1.05)$ & $1.03(0.94-1.13)$ & $0.96(0.90-1.02)$ \\
\hline Calibrated & $0.94(0.89-0.99)$ & $0.96(0.88-1.05)$ & $0.95(0.83-1.09)$ & $0.90(0.75-1.08)$ & $0.91(0.81-1.02)$ \\
\hline Fruit & $0.97(0.94-1.01)$ & $0.96(0.90-1.02)$ & $0.94(0.85-1.03)$ & $1.06(0.95-1.19)$ & $0.93(0.86-1.02)$ \\
\hline Calibrated & $0.94(0.88-1.01)$ & $0.93(0.83-1.05)$ & $0.94(0.79-1.11)$ & $1.01(0.80-1.26)$ & $0.89(0.77-1.02)$ \\
\hline Vegetables & $0.99(0.94-1.04)$ & $0.99(0.91-1.08)$ & $1.04(0.92-1.18)$ & $0.95(0.79-1.15)$ & $1.00(0.90-1.12)$ \\
\hline Calibrated & $0.94(0.83-1.07)$ & $1.04(0.84-1.29)$ & $1.03(0.72-1.45)$ & $0.69(0.42-1.13)$ & $0.93(0.71-1.23)$ \\
\hline Current smokers $(107,415)$ & 1,167 & 336 & 235 & 102 & 249 \\
\hline Fruit and vegetables & $0.96(0.93-0.99)$ & $0.93(0.87-0.99)$ & $0.96(0.88-1.04)$ & $1.03(0.92-1.14)$ & $0.94(0.87-1.02)$ \\
\hline Calibrated & $0.93(0.90-0.97)$ & $0.95(0.90-1.01)$ & $0.96(0.88-1.06)$ & $0.92(0.76-1.12)$ & $0.85(0.76-0.94)$ \\
\hline Fruit & $0.97(0.93-1.02)$ & $0.94(0.86-1.03)$ & $0.93(0.83-1.04)$ & $1.05(0.93-1.20)$ & $0.92(0.83-1.03)$ \\
\hline Calibrated & $0.97(0.92-1.02)$ & $0.99(0.91-1.08)$ & $0.97(0.86-1.10)$ & $0.97(0.77-1.22)$ & $0.87(0.77-0.98)$ \\
\hline Vegetables & $0.94(0.88-1.01)$ & $0.90(0.79-1.03)$ & $1.02(0.87-1.18)$ & $0.95(0.75-1.20)$ & $0.98(0.85-1.13)$ \\
\hline Calibrated & $0.89(0.82-0.97)$ & $0.89(0.77-1.02)$ & $0.98(0.82-1.17)$ & $0.87(0.55-1.38)$ & $0.85(0.72-1.00)$ \\
\hline Former smokers $(127,530)$ & 467 & 161 & $45^{\mathrm{a}}$ & $25^{\mathrm{a}}$ & 104 \\
\hline Fruit and vegetables & $1.00(0.96-1.05)$ & $1.01(0.94-1.09)$ & & & $1.00(0.90-1.10)$ \\
\hline Calibrated & $0.97(0.83-1.15)$ & $0.95(0.69-1.30)$ & & & $0.96(0.68-1.36)$ \\
\hline Fruit & $0.97(0.91-1.04)$ & $0.99(0.88-1.11)$ & & & $0.96(0.84-1.10)$ \\
\hline Calibrated & $0.95(0.83-1.08)$ & $0.91(0.72-1.15)$ & & & $0.98(0.77-1.25)$ \\
\hline Vegetables & $1.04(0.96-1.13)$ & $1.04(0.90-1.20)$ & & & $1.06(0.88-1.27)$ \\
\hline Calibrated & $1.06(0.86-1.30)$ & $1.12(0.78-1.62)$ & & & $0.97(0.63-1.50)$ \\
\hline Never smokers $(236,426)$ & 187 & $76^{\mathrm{a}}$ & $2^{\mathrm{a}}$ & $10^{\mathrm{a}}$ & $9^{\mathrm{a}}$ \\
\hline Fruit and vegetables & $1.00(0.93-1.07)$ & & & & \\
\hline Calibrated & $1.02(0.86-1.21)$ & & & & \\
\hline Fruit & $1.01(0.92-1.11)$ & & & & \\
\hline Calibrated & $1.03(0.82-1.30)$ & & & & \\
\hline Vegetables & $0.99(0.87-1.12)$ & & & & \\
\hline Calibrated & $1.00(0.69-1.43)$ & & & & \\
\hline Women $(335,886)$ & 866 & 307 & 123 & 63 & 102 \\
\hline Fruit and vegetables & $0.97(0.93-1.01)$ & $0.97(0.91-1.04)$ & $0.94(0.84-1.05)$ & & $0.91(0.80-1.04)$ \\
\hline Calibrated & $0.91(0.83-0.99)$ & $0.88(0.75-1.02)$ & $0.92(0.72-1.17)$ & & $0.78(0.60-1.02)$ \\
\hline Fruit & $0.96(0.91-102)$ & $0.97(0.88-1.06)$ & $0.83(0.71-0.99)$ & & $0.93(0.78-1.11)$ \\
\hline Calibrated & $0.91(0.80-1.03)$ & $0.84(0.67-1.05)$ & $0.69(0.47-1.02)$ & & $0.88(0.60-1.29)$ \\
\hline Vegetables & $0.98(0.91-1.05)$ & $0.98(0.87-1.11)$ & $1.12(0.93-1.34)$ & & $0.88(0.68-1.13)$ \\
\hline Calibrated & $0.92(0.77-1.10)$ & $0.94(0.71-1.25)$ & $1.65(0.94-2.90)$ & & $0.59(0.35-0.99)$ \\
\hline Men $(142,649)$ & 964 & 267 & 163 & 74 & 261 \\
\hline Fruit and vegetables & $0.99(0.96-1.02)$ & $0.97(0.91-1.04)$ & $1.00(0.92-1.09)$ & & $0.98(0.91-1.04)$ \\
\hline Calibrated & $0.91(0.85-0.98)$ & $0.92(0.79-1.06)$ & $0.95(0.78-1.15)$ & & $0.91(0.79-1.05)$ \\
\hline Fruit & $0.98(0.94-1.03)$ & $0.95(0.87-1.05)$ & $1.00(0.89-1.13)$ & & $0.94(0.85-1.03)$ \\
\hline Calibrated & $0.92(0.84-1.00)$ & $0.88(0.73-1.05)$ & $1.01(0.81-1.25)$ & & $0.87(0.72-1.04)$ \\
\hline Vegetables & $1.00(0.94-1.07)$ & $1.01(0.88-1.15)$ & $1.00(0.84-1.18)$ & & $1.04(0.92-1.18)$ \\
\hline Calibrated & $0.94(0.81-1.10)$ & $1.10(0.82-1.48)$ & $0.87(0.59-1.28)$ & & $1.05(0.76-1.43)$ \\
\hline
\end{tabular}

Cox regression model adjusted for smoking status, duration of smoking, lifetime and baseline intensity of smoking, time since quitting, energy intake, weight, height, alcohol consumption, physical activity, and school level

${ }^{\text {a }}$ Too few cases to get reliable results 
Table 5 Fully adjusted hazard ratios for different histological subtypes of lung cancer by increasing observed and calibrated, total fruit (per $100 \mathrm{~g} / \mathrm{day}$ ) and fruit subgroup consumption (per $25 \mathrm{~g} /$ day) for the full cohort and current smokers separately

$\begin{array}{lllll}\begin{array}{l}\text { Lung cancer } \\ (n=1,830)\end{array} & \begin{array}{l}\text { Adenocarcinoma } \\ (n=574)\end{array} & \begin{array}{l}\text { Small cell carcinoma } \\ (n=286)\end{array} & \begin{array}{l}\text { Large cell carcinoma } \\ (n=137)\end{array} & \begin{array}{l}\text { Squamous cell carcinoma } \\ (n=363)\end{array}\end{array}$

Full cohort

\begin{tabular}{|c|c|c|c|c|c|}
\hline Hard fruit & $0.99(0.97-1.01)$ & $0.99(0.96-1.02)$ & $1.00(0.96-1.05)$ & $1.00(0.95-1.06)$ & $1.01(0.97-1.04)$ \\
\hline Calibrated & $0.99(0.96-1.02)$ & $0.97(0.92-1.02)$ & $1.01(0.95-1.09)$ & $1.01(0.90-1.13)$ & $1.02(0.96-1.07)$ \\
\hline Stone fruit ${ }^{\mathrm{a}}$ & $1.01(0.97-1.06)$ & $0.97(0.89-1.06)$ & $1.01(0.88-1.16)$ & $1.08(0.92-1.27)$ & $0.97(0.86-1.10)$ \\
\hline Calibrated & $0.97(0.90-1.06)$ & $1.03(0.91-1.18)$ & $0.93(0.75-1.15)$ & $0.98(0.73-1.32)$ & $0.82(0.68-1.00)$ \\
\hline Berries $^{\mathrm{b}}$ & $1.07(0.96-1.19)$ & $1.02(0.84-1.24)$ & $1.13(0.89-1.44)$ & $1.10(0.83-1.45)$ & $1.08(0.84-1.39)$ \\
\hline Calibrated & $0.78(0.63-0.96)$ & $0.76(0.51-1.13)$ & $0.88(0.50-1.54)$ & $0.76(0.29-1.98)$ & $0.72(0.38-1.35)$ \\
\hline Grapes $^{\mathrm{a}, \mathrm{c}}$ & $1.07(0.99-1.15)$ & $0.98(0.82-1.18)$ & $1.02(0.78-1.32)$ & $\mathrm{d}$ & $0.92(0.72-1.18)$ \\
\hline Calibrated & $1.00(0.91-1.10)$ & $0.87(0.71-1.05)$ & $1.02(0.77-1.36)$ & d & $0.93(0.75-1.14)$ \\
\hline Citrus fruit $^{\mathrm{e}}$ & $0.99(0.96-1.02)$ & $0.95(0.90-1.01)$ & $0.95(0.87-1.02)$ & $1.05(0.97-1.14)$ & $0.94(0.87-1.01)$ \\
\hline Calibrated & $0.99(0.94-1.04)$ & $0.97(0.90-1.05)$ & $0.96(0.86-1.07)$ & $1.05(0.89-1.23)$ & $0.97(0.89-1.07)$ \\
\hline Citrus fruit incl juice $e^{b, e, f}$ & $1.00(0.98-1.01)$ & $0.98(0.95-1.01)$ & $0.99(0.96-1.03)$ & $1.03(0.98-1.09)$ & $1.00(0.96-1.04)$ \\
\hline Calibrated & $1.00(0.98-1.03)$ & $0.98(0.93-1.02)$ & $0.99(0.95-1.04)$ & $1.02(0.94-1.09)$ & $1.03(0.99-1.08)$ \\
\hline \multicolumn{6}{|l|}{ Current smokers } \\
\hline Hard fruit & $1.00(0.98-1.02)$ & $0.99(0.95-1.04)$ & $1.00(0.96-1.06)$ & d & $1.02(0.98-1.07)$ \\
\hline Calibrated & $0.99(0.97-1.01)$ & $1.01(0.97-1.04)$ & $1.01(0.96-1.06)$ & d & $0.99(0.95-1.03)$ \\
\hline Stone fruit ${ }^{\mathrm{a}}$ & $0.97(0.91-1.04)$ & $0.94(0.83-1.08)$ & $1.04(0.89-1.20)$ & $\mathrm{d}$ & $0.96(0.82-1.13)$ \\
\hline Calibrated & $0.99(0.95-1.04)$ & $1.03(0.96-1.09)$ & $1.03(0.91-1.17)$ & d & $0.97(0.88-1.07)$ \\
\hline Berries $^{b}$ & $0.97(0.83-1.12)$ & $0.88(0.65-1.19)$ & $1.19(0.91-1.55)$ & $\mathrm{d}$ & $0.91(0.62-1.34)$ \\
\hline Calibrated & $0.90(0.78-1.04)$ & $0.85(0.69-1.04)$ & $1.11(0.76-1.62)$ & d & $0.87(0.61-1.26)$ \\
\hline Grapes $^{\mathrm{b}, \mathrm{c}}$ & $1.12(1.03-1.21)$ & $1.10(0.93-1.31)$ & $1.07(0.80-1.42)$ & d & $0.99(0.72-1.38)$ \\
\hline Calibrated & $0.99(0.94-1.04)$ & $1.01(0.93-1.10)$ & $0.89(0.75-1.05)$ & d & $0.97(0.85-1.10)$ \\
\hline Citrus fruit ${ }^{\mathrm{e}}$ & $0.99(0.95-1.02)$ & $0.96(0.89-1.03)$ & $0.96(0.88-1.05)$ & $\mathrm{d}$ & $0.89(0.80-0.98)$ \\
\hline Calibrated & $1.01(0.98-1.03)$ & $0.99(0.94-1.04)$ & $1.03(0.94-1.12)$ & $\mathrm{d}$ & $0.91(0.84-1.00)$ \\
\hline Citrus fruit incl juice ${ }^{b, e, f}$ & $1.00(0.98-1.02)$ & $0.98(0.94-1.02)$ & $0.99(0.94-1.03)$ & $\mathrm{d}$ & $0.99(0.94-1.04)$ \\
\hline Calibrated & $1.00(0.98-1.02)$ & $0.99(0.96-1.04)$ & $0.98(0.94-1.02)$ & $\mathrm{d}$ & $1.02(0.97-1.06)$ \\
\hline
\end{tabular}

Cox regression model adjusted for vegetable consumption, smoking status, duration of smoking, lifetime and baseline intensity of smoking, time since quitting, energy intake, weight, height, alcohol consumption, physical activity, and school level

${ }^{\text {a }}$ Umea and Norway excluded because of missing data

${ }^{\mathrm{b}}$ United Kingdom and Norway excluded because of missing data

${ }^{c}$ Denmark excluded because of missing data

d Too few cases to get reliable results

e Spain excluded because of missing data

${ }^{\mathrm{f}}$ France and Naples excluded because of missing data

Out of all types of fruits tested, after calibration only consumption of berries was inversely associated with risk of lung cancer (HR 0.78; 95\% CI 0.63-0.96), with no clear difference between subtypes of lung cancer. An inverse association was found between the consumption of citrus fruits and squamous cell carcinomas in current smokers, which was borderline statistically significant (Table 5).

To control for potential changes in diet due to preclinical diseases, we excluded the first 2 years of follow-up. The inverse association between fruit consumption and lung cancer risk became somewhat stronger (HR 0.96; $95 \%$ CI 0.92-0.99 per $100 \mathrm{~g} /$ day increase in consumption) with a calibrated continuous risk estimate of 0.92 (95\% CI 0.85 1.00) for each $100 \mathrm{~g} / \mathrm{d}$ increase in consumption. Analyzing below and above median follow-up ( 8.5 years) separately showed results comparable to the overall analyses for below median follow-up (uncalibrated HR $0.98,95 \%$ CI 0.94-1.02 per $100 \mathrm{~g} /$ day increase in consumption) whereas no association was seen for follow-up periods longer than the mean of 8.7 years (uncalibrated HR 1.00, 95\% CI 0.911.10 per $100 \mathrm{~g} /$ day increase in consumption). 
Table 6 Fully adjusted hazard ratios for different histological subtypes of lung cancer by quintiles (cut point of the quintiles are (g/day): $\leq 97$; 98-146; 147-208; 209-306; $\geq 307$ ) of observed vegetable consumption for the full cohort, by smoke status and by gender

\begin{tabular}{|c|c|c|c|c|c|}
\hline $\begin{array}{l}\text { Vegetable consumption } \\
\text { (gram per day) }\end{array}$ & Lung cancer & Adenocarcinoma & $\begin{array}{l}\text { Small cell } \\
\text { carcinoma }\end{array}$ & $\begin{array}{l}\text { Large cell } \\
\text { carcinoma }\end{array}$ & $\begin{array}{l}\text { Squamous cell } \\
\text { carcinoma }\end{array}$ \\
\hline Full cohort $(478,535)$ & 1,830 & 574 & 286 & 137 & 363 \\
\hline Q1 & 1.00 & 1.00 & 1.00 & 1.00 & 1.00 \\
\hline Q2 & $1.00(0.87-1.14)$ & $0.89(0.70-1.12)$ & $1.17(0.85-1.62)$ & $0.76(0.47-1.21)$ & $1.05(0.78-1.40)$ \\
\hline Q3 & $0.94(0.82-1.09)$ & $0.86(0.67-1.11)$ & $1.09(0.76-1.56)$ & $0.84(0.51-1.38)$ & $0.83(0.59-1.16)$ \\
\hline Q4 & $0.94(0.80-1.11)$ & $0.91(0.68-1.21)$ & $1.18(0.77-1.79)$ & $0.81(0.45-1.46)$ & $0.97(0.68-1.39)$ \\
\hline Q5 & $0.96(0.79-1.17)$ & $1.10(0.78-1.55)$ & $1.17(0.67-2.02)$ & $0.81(0.38-1.72)$ & $0.96(0.62-1.50)$ \\
\hline$p$ for trend & 0.58 & 0.66 & 0.57 & 0.55 & 0.75 \\
\hline Current smokers $(107,415)$ & 1,167 & 336 & 235 & 102 & 249 \\
\hline Q1 & 1.00 & 1.00 & 1.00 & 1.00 & 1.00 \\
\hline Q2 & $1.13(0.96-1.32)$ & $0.98(0.73-1.31)$ & $1.23(0.86-1.76)$ & $0.95(0.57-1.61)$ & $1.31(0.94-1.82)$ \\
\hline Q3 & $0.90(0.75-1.08)$ & $0.83(0.59-1.16)$ & $1.19(0.80-1.77)$ & $0.90(0.50-1.62)$ & $0.69(0.44-1.06)$ \\
\hline Q4 & $0.94(0.77-1.16)$ & $0.94(0.64-1.37)$ & $1.41(0.90-2.21)$ & $0.79(0.38-1.65)$ & $1.00(0.64-1.55)$ \\
\hline Q5 & $0.87(0.66-1.13)$ & $0.89(0.54-1.48)$ & $0.84(0.42-1.69)$ & $0.80(0.30-2.14)$ & $0.87(0.47-1.59)$ \\
\hline$p$ for trend & 0.15 & 0.55 & 0.87 & 0.56 & 0.39 \\
\hline Former smokers $(127,530)$ & 467 & 161 & $45^{\mathrm{a}}$ & $25^{\mathrm{a}}$ & 104 \\
\hline Q1 & 1.00 & 1.00 & & & 1.00 \\
\hline Q2 & $0.79(0.59-1.07)$ & $0.90(0.57-1.44)$ & & & $0.54(0.27-1.09)$ \\
\hline Q3 & $1.00(0.74-1.34)$ & $0.85(0.52-1.40)$ & & & $1.23(0.67-2.27)$ \\
\hline Q4 & $0.81(0.58-1.13)$ & $0.70(0.40-1.24)$ & & & $0.89(0.45-1.78)$ \\
\hline Q5 & $1.04(0.73-1.49)$ & $1.13(0.62-2.06)$ & & & $1.06(0.51-2.23)$ \\
\hline$p$ for trend & 0.62 & 0.77 & & & 0.54 \\
\hline Never smokers $(236,426)$ & 187 & 76 & $2^{\mathrm{a}}$ & $10^{\mathrm{a}}$ & $9^{\mathrm{a}}$ \\
\hline Q1 & 1.00 & 1.00 & & & \\
\hline Q2 & $0.59(0.34-1.02)$ & $0.46(0.21-1.04)$ & & & \\
\hline Q3 & $0.96(0.59-1.58)$ & $0.96(0.48-1.92)$ & & & \\
\hline Q4 & $0.99(0.59-1.66)$ & $1.04(0.48-2.24)$ & & & \\
\hline Q5 & $0.81(0.46-1.45)$ & $1.32(0.55-3.17)$ & & & \\
\hline$p$ for trend & 0.90 & 0.24 & & & \\
\hline Women $(335,886)$ & 866 & 307 & 123 & 63 & 102 \\
\hline Q1 & 1.00 & 1.00 & 1.00 & 1.00 & 1.00 \\
\hline Q2 & $0.85(0.70-1.05)$ & $0.90(0.65-1.25)$ & $0.93(0.57-1.54)$ & $0.50(0.23-1.12)$ & $0.87(0.51-1.49)$ \\
\hline Q3 & $0.91(0.74-1.12)$ & $0.93(0.66-1.30)$ & $0.81(0.47-1.40)$ & $1.10(0.55-2.20)$ & $0.80(0.44-1.45)$ \\
\hline Q4 & $0.93(0.74-1.16)$ & $0.98(0.67-1.44)$ & $0.92(0.49-1.75)$ & $1.56(0.72-3.35)$ & $0.95(0.48-1.85)$ \\
\hline Q5 & $0.89(0.68-1.17)$ & $1.05(0.66-1.69)$ & $1.51(0.71-3.21)$ & $0.95(0.31-2.97)$ & $0.64(0.24-1.70)$ \\
\hline$p$ for trend & 0.60 & 0.76 & 0.45 & 0.41 & 0.45 \\
\hline Men $(142,649)$ & 964 & 267 & 163 & 74 & 261 \\
\hline Q1 & 1.00 & 1.00 & 1.00 & 1.00 & 1.00 \\
\hline Q2 & $1.14(0.95-1.36)$ & $0.88(0.63-1.24)$ & $1.42(0.92-2.18)$ & $1.02(0.57-1.83)$ & $1.15(0.81-1.63)$ \\
\hline Q3 & $0.97(0.79-1.19)$ & $0.78(0.53-1.16)$ & $1.38(0.85-2.24)$ & $0.65(0.31-1.38)$ & $0.85(0.57-1.28)$ \\
\hline Q4 & $0.95(0.75-1.20)$ & $0.84(0.54-1.30)$ & $1.48(0.84-2.60)$ & $0.36(0.13-0.99)$ & $1.01(0.66-1.54)$ \\
\hline Q5 & $1.04(0.79-1.37)$ & $1.20(0.72-1.99)$ & $0.97(0.45-2.13)$ & $0.65(0.23-1.81)$ & $1.09(0.66-1.82)$ \\
\hline$p$ for trend & 0.89 & 0.66 & 0.79 & 0.14 & 0.88 \\
\hline
\end{tabular}

Cox regression model adjusted for fruit consumption, smoking status, duration of smoking, lifetime and baseline intensity of smoking, time since quitting, energy intake, weight, height, alcohol consumption, physical activity, and school level

${ }^{a}$ Too few cases to get reliable results 
Vegetables

In categorical and continuous analyses, consumption of vegetables was not associated with risk of lung cancer nor with risk of any of the histological subtypes (Tables 4, 6). However, in current smokers after calibration, a statistically significantly inverse association with the consumption of total vegetables was seen, that was borderline statistically significant only for risk of squamous cell carcinomas (Table 4). The test for interaction with smoking was borderline significant ( $p$ 0.05).

Only after calibration, consumption of leafy vegetables was inversely associated with lung cancer risk, while no statistically significant associations were seen for histological subtypes of lung cancer (Table 7). Also only after calibration, an increase in consumption of cabbages of $25 \mathrm{~g} /$ day was statistically significantly inversely associated with squamous cell carcinomas. In current smokers, none of the subtypes of vegetables was statistically significantly associated with any of the histological subtypes of lung cancer.

The results for vegetable consumption did not change when we excluded the first 2 years of follow-up nor when we analyzed the cohort below and above median follow-up (8.5 years) separately (data not shown).

\section{Discussion}

In line with the previous EPIC study on fruit and vegetable consumption and lung cancer risk [8], we too found inverse

Table 7 Fully adjusted hazard ratios for different histological subtypes of lung cancer by increasing observed and calibrated total vegetables (per $100 \mathrm{~g} /$ day) and vegetable subgroup consumption (per $25 \mathrm{~g} /$ day) for the full cohort and current smokers separately

\begin{tabular}{|c|c|c|c|c|c|}
\hline & $\begin{array}{l}\text { Lung cancer } \\
(n=1,830)\end{array}$ & $\begin{array}{l}\text { Adenocarcinoma } \\
(n=574)\end{array}$ & $\begin{array}{l}\text { Small cell carcinoma } \\
(n=286)\end{array}$ & $\begin{array}{l}\text { Large cell carcinoma } \\
(n=137)\end{array}$ & $\begin{array}{l}\text { Squamous cell carcinoma } \\
(n=363)\end{array}$ \\
\hline \multicolumn{6}{|l|}{ Full Cohort } \\
\hline Leafy vegetables ${ }^{\mathrm{a}}$ & $0.99(0.94-1.03)$ & $1.01(0.93-1.11)$ & $0.96(0.82-1.13)$ & $1.02(0.87-1.18)$ & $0.96(0.85-1.08)$ \\
\hline Calibrated & $0.85(0.74-0.98)$ & $0.86(0.67-1.11)$ & $0.91(0.62-1.33)$ & $0.78(0.49-1.25)$ & $0.94(0.70-1.26)$ \\
\hline Fruiting vegetables & $1.00(0.98-1.03)$ & $0.98(0.94-1.04)$ & $1.04(0.97-1.10)$ & $0.92(0.82-1.02)$ & $1.04(0.98-1.10)$ \\
\hline Calibrated & $0.99(0.94-1.05)$ & $0.99(0.89-1.10)$ & $1.07(0.92-1.24)$ & $0.81(0.64-1.02)$ & $1.05(0.92-1.21)$ \\
\hline Cabbage $^{\mathrm{a}}$ & $1.00(0.96-1.05)$ & $1.03(0.94-1.12)$ & $1.01(0.87-1.14)$ & $0.97(0.79-1.20)$ & $0.98(0.89-1.09)$ \\
\hline Calibrated & $1.06(0.95-1.18)$ & $1.24(1.01-1.52)$ & $1.11(0.84-1.47)$ & $0.87(0.57-1.34)$ & $0.77(0.61-0.97)$ \\
\hline Root vegetables & $1.01(0.97-1.06)$ & $1.04(0.97-1.12)$ & $0.96(0.84-1.09)$ & $1.05(0.90-1.23)$ & $1.06(0.97-1.17)$ \\
\hline Calibrated & $0.99(0.89-1.11)$ & $1.10(0.95-1.27)$ & $0.87(0.68-1.11)$ & $1.03(0.66-1.60)$ & $1.10(0.91-1.33)$ \\
\hline Mushrooms $^{\mathrm{a}, \mathrm{b}}$ & $0.82(0.68-1.00)$ & $0.91(0.64-1.29)$ & $0.97(0.60-1.57)$ & $0.32(0.09-1.10)$ & $0.48(0.28-0.81)$ \\
\hline Calibrated & $0.96(0.62-1.50)$ & $0.85(0.39-1.83)$ & $0.90(0.32-2.53)$ & $0.23(0.03-1.98)$ & $0.57(0.22-1.45)$ \\
\hline Onion and Garlic $\mathrm{c}^{\mathrm{a}, \mathrm{b}, \mathrm{c}}$ & $0.95(0.84-1.06)$ & $1.00(0.82-1.22)$ & $1.05(0.80-1.38)$ & $0.70(0.43-1.13)$ & $0.90(0.70-1.15)$ \\
\hline Calibrated & $0.92(0.71-1.18)$ & $1.14(0.72-1.78)$ & $0.71(0.36-1.38)$ & $0.59(0.22-1.55)$ & $0.89(0.52-1.52)$ \\
\hline \multicolumn{6}{|l|}{ Current smokers } \\
\hline Leafy vegetables ${ }^{a}$ & $0.97(0.91-1.04)$ & $1.02(0.90-1.15)$ & $0.94(0.79-1.12)$ & d & $0.98(0.84-1.13)$ \\
\hline Calibrated & $0.96(0.90-1.02)$ & $0.92(0.81-1.05)$ & $1.11(0.91-1.35)$ & d & $0.96(0.80-1.14)$ \\
\hline Fruiting vegetables & $1.01(0.97-1.04)$ & $0.96(0.90-1.04)$ & $1.03(0.95-1.12)$ & d & $1.04(0.97-1.11)$ \\
\hline Calibrated & $0.97(0.94-1.00)$ & $0.97(0.93-1.02)$ & $0.98(0.91-1.05)$ & d & $0.98(0.92-1.04)$ \\
\hline Cabbage $^{\mathrm{b}}$ & $1.00(0.93-1.08)$ & $1.07(0.94-1.22)$ & $0.96(0.81-1.14)$ & d & $0.90(0.76-1.06)$ \\
\hline Calibrated & $0.96(0.91-1.01)$ & $0.99(0.93-1.06)$ & $1.06(0.92-1.23)$ & d & $0.94(0.85-1.04)$ \\
\hline Root vegetables & $0.97(0.91-1.04)$ & $0.96(0.85-1.08)$ & $0.98(0.85-1.14)$ & d & $1.09(0.97-1.23)$ \\
\hline Calibrated & $1.01(0.94-1.08)$ & $1.01(0.92-1.10)$ & $0.93(0.78-1.10)$ & d & $1.05(0.91-1.21)$ \\
\hline Mushrooms ${ }^{\mathrm{a}, \mathrm{b}}$ & $0.75(0.57-0.99)$ & $0.86(0.53-1.40)$ & $1.09(0.63-1.91)$ & d & $0.37(0.18-0.78)$ \\
\hline Calibrated & $1.12(0.86-1.46)$ & $1.03(0.58-1.83)$ & $0.88(0.42-1.84)$ & d & $0.90(0.48-1.67)$ \\
\hline Onion and Garlic $c^{a, b, c}$ & $0.95(0.82-1.10)$ & $0.98(0.75-1.27)$ & $1.13(0.85-1.51)$ & d & $1.00(0.75-1.34)$ \\
\hline Calibrated & $0.98(0.86-1.11)$ & $0.93(0.75-1.15)$ & $1.01(0.75-1.38)$ & d & $1.04(0.82-1.32)$ \\
\hline
\end{tabular}

Cox regression model adjusted for fruit consumption, smoking status, duration of smoking, lifetime and baseline intensity of smoking, time since quitting, energy intake, weight, height, alcohol consumption, physical activity, and school level

${ }^{\text {a }}$ Norway excluded because of missing data

${ }^{\mathrm{b}}$ Umea excluded because of missing data

${ }^{c}$ France excluded because of missing data

${ }^{\mathrm{d}}$ Too few cases to get reliable results 
associations between the consumption of vegetables and fruits combined and of fruits and risk of lung cancer. In this study, we additionally looked at fruit and vegetable consumption and the different histological subtypes of lung cancer. However, we did not see a clear effect of consumption of fruit and/or vegetables on risks for specific histological subtypes of lung cancer. In current smokers, we found that the consumption of vegetables and fruits combined and separately may reduce lung cancer risk, in particular the risk of squamous cell carcinoma. Several inverse associations between subgroups of fruits and of vegetables and risk of (types of) lung cancer were seen, i.e., between leafy vegetables and berries and overall lung cancer; between cabbages and squamous cell carcinomas; in current smokers between citrus fruits and squamous cell carcinomas.

The 2007 WCRF/AICR expert report, including only the first EPIC publication on fruit and vegetable consumption and lung cancer risk by Miller et al. [6], concluded that the evidence of a inverse relationship between increased fruit consumption and decreased lung cancer risk is consistent and that there is a dose-response relationship both found in cohort and case-control studies [2]. Our study is in line with these findings. Intake of fruits was inversely related to the risk of lung cancer in categorical but not continuous analyses, but this difference could be explained by the effect of outliers. Out of 6 types of fruits, only intake of berries was inversely related to lung cancer risk. Two previous Finish cohort studies found opposite results for the effect of berries on lung cancer risk [14, 15]. On the other hand, studies on the intake of vegetables and risk of total lung cancer have been inconsistent. Some found an inverse association while others have not been able to reproduce these findings. A protective effect of total vegetable consumption was also not observed in the study by Miller et al. and other previous investigations [6, 16-19]. Vegetables are generally considered as food items that are not very easy to assess in food frequency questionnaires (as well as in other methods of dietary assessment). Indeed, within the EPIC validation studies, the correlation coefficients for total vegetable consumption were in general lower than those for fruits [20]. In our study, no evidence was seen for the consumption of total vegetables and overall lung cancer risk with HR 0.99 and 95\% CI 0.94 1.04. After calibration, this effect was somewhat stronger but still not statistically significant. However, after calibration, we did find a $15 \%$ decrease in lung cancer risk with an increased consumption of leafy vegetables of $25 \mathrm{~g} /$ day. This is in agreement with the meta-analysis based on three cohort studies $[16,21]$ performed by WCRF/AICR that found an overall RR of 0.91 (95\% CI 0.90-0.93) with increments of 1 serving/day of green leafy vegetables, although this result mainly depends on one large cohort study from Japan [21]. The expert panel of WCRF/AICR also found substantial evidence that food containing carotenoids, like carrots, probably protect against lung cancer. However, we did not find any association between increased root vegetable consumption and lung cancer risk.

Due to a larger number of cases, we were able to focus on risks of histological subgroups of lung cancer. Few previous cohort studies have analyzed the effect of fruits and vegetables on different histological subtypes of lung tumors [7, 22-24]. Most studies have divided lung tumors into two groups; Kreyberg I (comprising small cell carcinomas, squamous cell carcinomas, and large cell carcinomas) and Kreyberg II (adenocarcinomas). There were indications that fruits and vegetables were more protective for non-adenocarcinomas (Kreyberg I) than for adenocarcinomas (Kreyberg II). Voorrips et al. [22] found a protective effect of high intake of fruits in Kreyberg I tumors. In the study of Skuladottir et al. [23], a protective effect was found for fruits on squamous cell carcinomas, and an inverse association was found for vegetables on small cell carcinomas. No association for the intake of fruits and vegetables and any histological subtypes of lung cancer were reported by Liu et al. [17] and Feskanich et al.[16]. Some case-control studies have also reported that vegetables play a more beneficial role for non-adenocarcinomas than for adenocarcinomas [25, 26]. Still, it is difficult to compare the studies because of different classifications for lung cancer subtypes, and because most studies have only a small number of cases for analyses. In our study, only $80 \%$ of the tumors were microscopically confirmed of which $82 \%$ histologically. This left us with 470 cases that could not be categorized in one of the four histological subgroups of lung cancer. Higher microscopic and histological confirmation rates would have given our analyses more power. We did not observe statistically significant inverse associations between consumption of fruit and/or vegetables and risks of the histological subtypes of lung cancer.

Many studies (retrospective and prospective) have indicated a clear protective effect of fruit and vegetables on lung cancer risk among current smokers only [7]. These studies suggested that antioxidants from vegetables and fruits strongly reduce the oxidative stress due to smoking. By contrast, others have found a stronger protective effect of fruits among non-smokers. It is argued that the inverse association among current smokers seen in some studies might be due to residual confounding by smoking [23]. In our study, among current smokers, inverse effects were seen for fruit and vegetables consumption combined and separately and lung cancer risk, which is in line with the previous study of Linseisen et al. 2007 [8] within the EPIC cohort and with the pooled analyses of cohort studies published by Smith-Warner et al. 2003 [7]. Additionally, 
we were able to classify risks by smoking status. In current smokers, statistically (borderline) significant inverse associations emerged between the consumption of fruit and vegetables combined and separately, and of citrus fruits and risk of squamous cell carcinomas, the type of lung cancer most strongly related to smoking.

Important advantages of our cohort study are its size and the large heterogeneity of fruit and vegetable consumption, caused by the inclusion of participants living in countries from the north to the south of Europe. However, despite using EPIC-wide cut points for construction of categories because of methodological differences between the participating countries, analyses were stratified by study center. To some extent, this counteracts the advantage of the large heterogeneity in dietary exposures.

Although evidence is accumulating that a diet rich in vegetables and fruits may indeed protect against lung cancer especially risk of squamous cell carcinoma in current smokers, the many associations tested in our study need to be replicated in independent large cohort studies to further investigate the role of types of fruit and vegetables in the development of histological subtypes of lung cancer.

In conclusion, we found inverse associations between the consumption of vegetables and fruits combined and of fruits and risk of lung cancer without a clear effect on risks for histological subtypes of lung cancer. In current smokers, consumption of vegetables and fruits combined and separately may reduce lung cancer risk, in particular risk of squamous cell carcinomas although residual confounding by smoking cannot be ruled out.

Acknowledgments The work described in this paper was carried out with the support of the European Commission: Public Health and Consumer Protection Directorate 1993-2004; Research DirectorateGeneral 2005; Ligue contre le Cancer, Societé $3 \mathrm{M}$, Mutuelle Générale de l'Education Nationale, Institut National de la Santé et de la Recherche Médicale (INSERM) (France); German Cancer Aid, German Cancer Research Center, Federal Ministry of Education and Research (Germany); Danish Cancer Society (Denmark); Health Research Fund (FIS) of the Spanish Ministry of Health, The participating regional governments and institutions (Spain); Cancer Research UK, Medical Research Council, Stroke Association, British Heart Foundation, Department of Health, Food Standards Agency, the Wellcome Trust (United Kingdom); Greek Ministry of Health and Social Solidarity, Hellenic Health Foundation and Stavros Niarchos Foundation (Greece); Italian Association for Research on Cancer, National Research Council (Italy); Dutch Ministry of Public Health, Welfare and Sports, Dutch Prevention Funds, LK Research Funds, Dutch ZON (Zorg Onderzoek Nederland), World Cancer Research Fund (WCRF) (the Netherlands); Swedish Cancer Society, Swedish Scientific Council, Regional Government of Skane (Sweden); Norwegian Cancer Society (Norway).

Open Access This article is distributed under the terms of the Creative Commons Attribution Noncommercial License which permits any noncommercial use, distribution, and reproduction in any medium, provided the original author(s) and source are credited.

\section{References}

1. Devesa S, Bray F, Vizcaino AP, Parkin DM (2005) International lung cancer trends by histologic type: male:female differences diminishing and adenocarcinoma rates rising. Int $\mathrm{J}$ Cancer 117:294-299

2. World Cancer Research Fund/American Institute for Cancer Research (WCRF/AICR) (2007) Food, nutrition, physical activity, and prevention of cancer: a global perspective. Washington: American Institute for Cancer Research

3. Parkin DM, Bray F, Ferlay J, Pisani P (2001) Estimating the world cancer burden: Globocan 2000. Int J Cancer 94:153-156

4. Khuder SA (2001) Effect of cigarette smoking on major histological types of lung cancer: a meta-analysis. Lung Cancer 31:139-148

5. Khuder SA, Mutgi AB (2001) Effect of smoking cessation on major histologic types of lung cancer. Chest 120:1577-1583

6. Miller AB, Altenburg HP, Bueno-de-Mesquita B et al (2004) Fruits and vegetables and lung cancer: findings from the European Prospective Investigation into Cancer and Nutrition. Int $\mathbf{J}$ Cancer 108:269-276

7. Smith-Warner SA, Spiegelman D, Yaun S, Yaun SS et al (2003) Fruits, vegetables and lung cancer: a pooled analysis of cohort studies. Int J Cancer 107:1001-1011

8. Linseisen J, Rohrmann S, Miller AB et al (2007) Fruit and vegetable consumption and lung cancer risk: updated information from the European Prospective Investigation into Cancer and Nutrition (EPIC). Int J Cancer 121:1103-1114

9. Riboli E, Hunt KJ, Slimani N et al (2002) European Prospective Investigation into Cancer and Nutrition (EPIC): study populations and data collection. Public Health Nutr 5:1113-1124

10. Agudo A, Slimani N, Ocke MC et al (2002) Consumption of vegetables, fruit and other plant foods in the European Prospective Investigation into Cancer and Nutrition (EPIC) cohorts from 10 European countries. Public Health Nutr 5:1179-1196

11. Jansen MC, Bueno-de-Mesquita HB, Feskens EJ et al (2004) Quantity and variety of fruit and vegetable consumption and cancer risk. Nutr Cancer 48:142-148

12. Ferrari P, Kaaks R, Fahey MT et al (2004) Within- and betweencohort variation in measured macronutrient intakes, taking account of measurement errors, in the European Prospective Investigation into Cancer and Nutrition study. Am J Epidemiol 160:814-822

13. Ferrari P, Day NE, Boshuizen HC et al (2008) The evaluation of the diet/disease relation in the EPIC study: considerations for the calibration and the disease models. Int J Epidemiol 37:368-378

14. Hirvonen T, Virtamo J, Korhonen P, Albanes D, Pietinen P (2001) Flavonol and flavone intake and the risk of cancer in male smokers (Finland). Cancer Causes Control 12:789-796

15. Knekt P, Jarvinen R, Seppanen R et al (1997) Dietary flavonoids and the risk of lung cancer and other malignant neoplasms. Am J Epidemiol 146:223-230

16. Feskanich D, Ziegler RG, Michaud DS et al (2000) Prospective study of fruit and vegetable consumption and risk of lung cancer among men and women. J Natl Cancer Inst 92:1812-1823

17. Liu Y, Sobue T, Otani T, Tsugane S (2004) Vegetables, fruit consumption and risk of lung cancer among middle-aged Japanese men and women: JPHC study. Cancer Causes Control $15: 349-357$

18. Jansen MC, Bueno-de-Mesquita HB, Rasanen L et al (2001) Cohort analysis of fruit and vegetable consumption and lung cancer mortality in European men. Int J Cancer 92:913-918

19. Knekt P, Jarvinen R, Teppo L, Aromaa A, Seppanen R (1999) Role of various carotenoids in lung cancer prevention. J Natl Cancer Inst 91:182-184 
20. Kaaks R, Slimani N, Riboli E (1997) Pilot phase studies on the accuracy of dietary intake measurements in the EPIC project: overall evaluation of results. European Prospective Investigation into Cancer and Nutrition. Int J Epidemiol 26(Suppl 1):S26-S36

21. Ozasa K, Watanabe Y, Ito Y et al (2001) Dietary habits and risk of lung cancer death in a large-scale cohort study (JACC Study) in Japan by sex and smoking habit. Jpn J Cancer Res 92:12591269

22. Voorrips LE, Goldbohm RA, Verhoeven DT et al (2000) Vegetable and fruit consumption and lung cancer risk in the Netherlands Cohort Study on diet and cancer. Cancer Causes Control $11: 101-115$
23. Skuladottir H, Tjoenneland A, Overvad K et al (2004) Does insufficient adjustment for smoking explain the preventive effects of fruit and vegetables on lung cancer? Lung Cancer 45:1-10

24. Wright ME, Park Y, Subar AF et al (2008) Intakes of fruit, vegetables, and specific botanical groups in relation to lung cancer risk in the NIH-AARP Diet and Health Study. Am J Epidemiol 168:1024-1034

25. Brennan P, Fortes C, Butler J et al (2000) A multicenter casecontrol study of diet and lung cancer among non-smokers. Cancer Causes Control 11:49-58

26. Axelsson G, Rylander R (2002) Diet as risk for lung cancer: a Swedish case-control study. Nutr Cancer 44:145-151 